\title{
Examination of the Corporate Role of Social Media - Slovak Case Study
}

DOI 10.18267/pr.2021.krn.4816.9

\author{
Enikő Korcsmáros ${ }^{1}$ - Bence Csinger 2 \\ ORCID iD: 0000-0002-2026-8712 ${ }^{1}$, 0000-0002-1348-4660² \\ korcsmarose@ujs.sk, csinger.bence@gmail.com \\ 1,2 J. Selye University, Faculty of Economics and Informatics, Department of \\ Economics \\ Komárno, Slovakia
}

\begin{abstract}
Social media is one of the most important corporate tools of the 21st century. In today's knowledge-based society, the most effective source of contact is the Internet, and within it, social media. The timeliness of our topic is that nowadays social media is one of the easiest solution for a company to reach the target audience, get feedback on its products/services, initiate instant communication that contributes to customer loyalty and it provides them free advertising opportunity. The aim of our research is to examine the role of social media in the life of enterprises in the Nitra district within Slovakia. The methodology of our study is based on a quantitative questionnaire survey. Our research covers small and medium-sized enterprises operating in Nitra district. In our study, as a first step, the development path of social media is presented, and then the methodology of the work, the results of the research, and the possible future directions of the study are presented. Our results provide the SME sector a comprehensive picture of why it is worthwhile to integrate social media into corporate life nowadays.
\end{abstract}

Keywords: corporate social media, small and medium-sized enterprises, integration, Slovakia, marketing strategy, corporate benefits

JEL Classification codes: M21, M30, M31

\section{INTRODUCTION}

The corporate importance of social media is on an ever-increasing trend. In terms of marketing, social media, in addition to being an optional element of the promotional mix, is a key component of the marketing strategy of many businesses. The businesses that are present on each social media platforms face a number of difficulties and challenges. The word of social media is changing at an extremely fast pace and it can be defined as a space where users expected to answer their questions within hours. If the company ignores this, it can provoke a global debate about the weaknesses of products/services that cause them economic harm. Companies need to place great emphasis on using innovative methods in the online space in order to reach their target audience on social media platforms. It can be useful for them to set goals such as the number of posts, the number of interactions, and the average response time. One of the main benefits of using social media in a business is that it can be measure a success of the organization. Examples of such metrics include the number of visits, page views, interaction rates, and the average time visitors spent on the corporate website. Various product overview websites, blogs and forums can be considered as a suitable learning tool from a corporate point of view, as on these platforms consumers share their individual experiences with the product/service. In addition to being valuable for the flow of information, social media 
also plays a key role in product development, collaborative projects, and the creation of social networks. However, it is not enough for a business to have only a presence on social media platforms, it is important that they respond to the changing needs of their target audience in order for their presence to be effective. From a corporate perspective, social media activities require strategic plans, clear internal rules, dedicated staff, and the right employees. (Aichner \& Jacob, 2015)

By using social media, businesses can use their organizational knowledge to create value for their customers in the form of extremely valuable public information that can help them make better decisions. Social media also allows businesses to customize the information they provide to customers, both in terms of content and appearance. This type of marketing activity creates an opportunity to improve the value chain of the business and creates added value in terms of both financial benefits and intangible assets (better network connections, proper communication). However, this wave of communication poses challenges and risks in developing new communication channels between businesses and their target audiences. Today, consumers demand that organizations listen to their opinions, reflect on them and incorporate them into organizational operations. (Roblek et al., 2013)

The impact of social media on the activities of organizations is significant and profound, which can be felt both at the level of marketing and information \& communication technologies. However, the online space has certain drawbacks on the user side that businesses need to consider when designing their marketing strategy. These activities include, for example, reputation loss, the unpredictability of the impact of people, the inability to manage the generational divide. (Georgescu-Popescul, 2015)

Over the past decade, social media has shown an ever-increasing trends in terms of the number of users. As a result, companies that have taken advantage of the opportunity and switched to the online space have been able to access information that they could use in product design, to facilitate brand communication, or even to market research, recruitment, networking and reputation management. (Risius \& Beck, 2015)

Based on these, the main goal of our study is to provide a comprehensive picture of the importance that small and medium-sized enterprises in the study region attach to corporate social media today, and thus to provide an insight into the opportunities and challenges of social media.

\section{LITERATURE REVIEW}

\subsection{The path of social media development in slovakia}

In the Slovak Internet environment, the supply of social media is decreasing. The main reason is probably found in language barriers. As a result, only global platforms that exist in the Slovak or Czech language versions (Facebook) or services that do not require foreign language skills (Youtube). (Murár, 2011)

With regard to Slovakia, five social media platforms are worth mentioning, which are:

- Spolužáci.cz

- Lidé.cz

- Líbímseti.cz

- Azet.sk

- Birdz.sk (Bazalová, 2012) 
The first such social media platform is Seznam Spolužáci, which was an Internet social server whose goals included transforming classmates into a community. The platform also included a notice board that could be found on the class's home page. This allowed them to insert text messages and add photos and videos, that were visible for everyone. Students also had an opportunity to edit their profile, insert a photo of themselves, and give themselves a nickname. They could initiate a conversation with someone other than their classmates. The website also provided an opportunity to organize class meetings. The site established relationship with people with whom one used to be in a class. The website was mostly used by the 25-35 age group. (Čapek, online)

In 2018, the website ceased operations after 14 years. At the beginning of 2018, the platform was used by more than 20,000 people a day, however the number of new users has been steadily declining, which the company began to feel in 2015. Although the service was primary intended for students, it can be said that it was much more used by graduates who maintained their relationships with each other through the site. As a result of the regulation on the protection of personal data, the managers had to completely change the service, which was too financially burdensome for them. The service operated until May 24, 2018, after which it was no longer possible to register a new user or upload a new photo. Until the end of August, all classes had the opportunity to download documents and photographs, and on September 1 , the service was permanently discontinued. (Aneta, 2018)

The Lidé.cz community server started operating in 1997. As more and more social platform appeared in the country, interest in the website began to decline. In 2014, due to this, the site underwent a radical change, as the platform started operating as a dating site from then on. However, this change did not save it either. Two years after Spolužáci, Seznam closed another community platform. (Sližzek, online)

The Líbímseti is based on a concept whose essence is that users have the opportunity to vote on how much they like other users on the platform. The Czech site, like Myspace, lost its popularity where it aroused interest. After a while, users are simply bored with the service, which is a good example for businesses that if they don' do enough to grow and get better, they won't be successful on social media because nothing lasts forever. The Czech service quickly attracted attention. However, with the advent of Facebook, the interest in the site began to decline. It was eventually sold in late 2010, when it had about 50,000 users a day. According to the creators, the biggest problem was that it focused on regions. (Tyinternety, online)

The next Slovak web portal is none other than Azet.sk. There are several milestones in the life of the company. In 1997, its founder, Milan Dubac, set up a Slovak dating service. Two years later Pokec.sk was established, which by 2001 became the most visited community site in Slovakia. The establishment of Azet.sk can be traced back to the year 2000. In 2005, Azet.sk launched the news sites Aktuality.sk as well as Sport.sk. Three years later, the founder of the competitor Zoznam.sk, Ivan Debnár, became the technical director of Azet.sk. In 2009 the company launched mapy.azet.sk, Najmama.sk and Kalendar.sk, acquired Slovnik.sk and Horoskopy.sk, and began working with Meteo.sk and Reality.sk. In 2010, the company acquired CPress Media, Žive.sk, and Mobilmania.sk, and acquired Hyperinzercia.sk for advertising services, which was redesigned and renamed to Bazar.sk. In 2012 the website Nehnutelnosti.sk with real estate ads was launched, as well as the website of the Slovak daily Cas.sk-Nový Čas. In 2013, they launched Byty.sk, Bistro.sk, and acquired Autovia.sk, as well as Superdeal.sk. In 2017, they bought DajmeJedlo.sk In the same year, the acquisition of Autobazar.EU, Topreality.sk, was announced. In 2015, the company achieved a turnover of 14 million euros. (Azet.sk, online)

The last worth mentioning website is Birdz.sk On December 4, 2000, Tomáš Abaffy created an online magazine with articles for students. The name of the magazine was changed 1 year 
later, from which time it operated under the name BIRDZ.SK. At the time, the site was just an online magazine where articles were written by the founder, and several other editors. It was introduced in 2002 as the website's slogan, which was: search your world. The brand gained its final form by 2003, which became a red sphere with the inscription BIRDZ inside. From the year 2004, BIRDZ started to become a community site. The very first community feature was dating. A year later, the slogan of the website changed to: your world. On the company's fifth anniversary, it transformed into a community portal where users could register, create their own profiles, upload photos, write blogs, and communicate with each other. In 2006, new features were added to the platforms, such as the Forum. Two years later, a strategic investor joined BIRDZ.SK, as the majority of the portal was acquired by Northcliffe International, an international media group. In the same year, BIRDZ allowed users to change the design of their own user account. It was the first company to launch a microblogging system. From the year 2009, BIRDZ became increasingly popular with users of video blogs, TV shows who were happy to answer other users' questions. In 2013, the creators of the platform simplified the design, moving to adaptive web design, which allowed the site to be used on both mobile phones and tablets. In 2015, BIRDZ underwent a huge transformation, with new features appearing thanks to Python. (Birdz, online)

\subsection{Opportunities and challenges in social media}

Social media allows companies to expand their marketing communication capabilities. Organizations need to monitor emerging community platforms in order to impact their target audience. Traditional marketing communications can be divided into paid and owned devices. In contrast, social media improves the ability of consumers to communicate with each other, by which earned media is also included in the marketing communication mix. As a result of community dialogues, a large amount of information is spread on each platform about the company's products/services. It is extremely important for organizations to learn how to respond to these dialogues. With the help of social media, they have the opportunity to listen to their customers on a wide scale, communicate with them, get them enthusiastic, and work with them to develop a product/service. Marketing managers have the opportunity and ability to observe and influence conversations in social media, communication becomes two-way. Companies need to treat a social media as a strategic tool, a long-term strategy that requires a sustained effort. Relevance, uniqueness, and creativity play a key role on social platforms. (Csordás et al., 2013)

Social media is a tool for people who usually have a common interest. Platforms provide a tremendous amount of opportunities for users to interact with each other. A user profile allows a company to obtain information about people with similar interests. This type of network provides an opportunity for targeted marketing. This type of activity can contribute to the successful operation of a company. One of the main benefits of social media is that the company is able to actively interact with consumers and also receive direct feedback from them through individual websites. To combination of so-called CRM (Customer Relationship Management) and social network provides an opportunity for businesses to take measurements of their social media activities. There are strategies to help organizations make better use of community platforms:

- Managing social networks as a new channel within CRM - Businesses need to seize the opportunity and use different CRM solutions to manage communications. You should continue to use client management tools after these activities move into the online world.

- $\quad$ Extending CRM through social networks 
- Using CRM and social networking sites together to get information about consumers to the company that they can analyze and respond to appropriately.

Social media marketing can be very beneficial for businesses. Creating communities around a particular product/service can be defined as a kind of potential strategy for building brand loyalty. Community platforms can help organizations to reach new consumers, build a brand, and conduct market research. Communication on social media encourages customers to listen to each other, review products/services, and access information. Social media provides a financially advantageous opportunity for companies to promote their company without having to create a huge marketing team. (Assaad \& Gómez, 2011)

Researchers agree that one of the most important features of social media is that they can generate and disseminate information from the user themselves, while in case of traditional media, the mode of dissemination is mainly one-way. While social media offers many opportunities, businesses also face a number of challenges. The rapid development of social media tracking a major challenge for businesses. It is a challenge for them to know exactly what information needs to be tracked and developed to perform the proper analyzes. From financial point of view, the return on online activities is not clear either, as sales do not always follow consumer needs, and it is important to pay attention to avoid mistakes, as a post can have a huge impact on the organization's reputation and credibility. In the case of social media, it is also important to mention certain ethical limitations. Recruiting and encouraging businesses as key users to influence brand communication leads to loss of credibility. Organizations need to keep in mind that this type of activity must also create social value in addition to commercial purposes. The privacy of users also raises ethical issues, as many people are unaware that they are being monitored. Misinterpretation of monitoring data can also be a challenge, as these messages can be interpreted in many ways. As a result of misinterpretation, the interpretation of monitoring data can be critical. In summary, in order to meet the challenges mentioned, it is important to have a good knowledge of the monitoring process, to find appropriate solutions, and to set clear goals. Challenges can become opportunities through appropriate solutions that are identified in front of competitors. (Zhang \& Vos, 2014)

\section{METHODOLOGY}

In our secondary research, we found few studies dealing with the development path of Slovak social media platforms and the importance that companies attach to the presence of social media in the country. As a result, the main aim of our study is to expand the literature on how social media in Slovakia has progressed to its current state and to provide answers to the question of how small and medium-sized enterprises operating in the Nitra district think about the corporate use of social media. The practical part of our research is based on a quantitative survey. In January 2021, we surveyed the importance of social media in the SME sector with the help of a questionnaire. As a first step, the questionnaire underwent a test phase, after which it was sent in the form of "direct mail" to the research subjects. Our quantitative survey was conducted using Survio and Google Form Builder software. The filling was done on the Internet in an anonymous form. Our questionnaire contained 27 questions. Our questions were divided into five categories, which are presented in Table 1. 
Tab. 1 Structure of a quantitative survey

\begin{tabular}{|l|l|l|l|l|}
\hline Question group 1. & Question group 2. & Question group 3. & Question group 4. & Question group 5. \\
\hline General information & $\begin{array}{l}\text { Issues related to } \\
\text { presence on social } \\
\text { media }\end{array}$ & $\begin{array}{l}\text { Use of feedback } \\
\text { information }\end{array}$ & $\begin{array}{l}\text { Future plans for } \\
\text { social media }\end{array}$ & $\begin{array}{l}\text { Success of } \\
\text { previously used } \\
\text { marketing tools }\end{array}$ \\
\hline
\end{tabular}

Source: own editing

In our study, 311 responses were received from small and medium-sized enterprises. The first step in our analysis was to encode the returned data using Microsoft Excel. The evaluation was performed using SPSS program. In examining our hypothesis, we used descriptive statistical methods, including cross-tabulation analysis. A significance level of $5 \%$ was determined during the evaluation. Chi-square test was used to analyze the variables, on the basis of which the Asssymp Sig helped to determine whether the null hypothesis or the alternative hypothesis is accepted for the given hypothesis.

\section{RESULTS AND DISCUSSION}

In this chapter of our study, the results of our research are presented. After reviewing the literature, the following research questions were formulated in us:

\section{RQ1: Nowadays, to what extend do small and medium-sized enterprises consider the use of social media at the enterprise level}

In our study, we would like to get an answer to the question of the extend to which the corporate application of social media is considered important by the managers of small and medium-sized enterprises operating in the Nitra district.

\section{RQ2: What future plans do the research subjects have for corporate social media?}

Our study also aims to explore the future plans of SME sector leaders for the enterprise application of social media. The answers to the research questions provide a comprehensive picture of how small and medium-sized enterprises in Nitra district think about the development direction of the corporate application of social media.

\subsection{Hypothesis testing}

The following hypothesis have been formulated on this topic:

Tab. 2 The formulated hypothesis

\begin{tabular}{|l|l|}
\hline H1 & $\begin{array}{l}\text { Small businesses are much more likely to be present on social media than medium-sized } \\
\text { enterprises. }\end{array}$ \\
\hline H2 & $\begin{array}{l}\text { Businesses that plan to expand the organization's presence on social media would most likely } \\
\text { implement their plans by involving influencers. }\end{array}$ \\
\hline
\end{tabular}

Source: Owned editing

When analyzing the first hypothesis, we obtained the following results: 
Tab. 3 Analysis of the first hypothesis

\begin{tabular}{|c|c|c|c|}
\hline \multicolumn{4}{|l|}{ Chi-Square Test } \\
\hline Statistics & Value & df & Asymptotic Significance (2-sided) \\
\hline Pearson Chi-Square & $1,032^{\mathrm{a}}$ & 2 & ,597 \\
\hline Likelihood Ratio & 1,021 & 2 & 600 \\
\hline $\mathrm{N}$ of Valid Cases & 311 & & \\
\hline \multicolumn{4}{|l|}{ Symmetric Measures } \\
\hline & & Value & Approximate Significance \\
\hline \multirow[t]{3}{*}{ Nominal by Nominal } & Phi & ,058 & ,597 \\
\hline & Cramer's V & ,058 & ,597 \\
\hline & $\begin{array}{l}\text { Contingency } \\
\text { Coefficient }\end{array}$ & ,058 & ,597 \\
\hline $\mathrm{N}$ of Valid Cases & & 311 & \\
\hline
\end{tabular}

Source: own editing based on primary data collection

In the case of the first hypothesis, it is clear that number of valid answers is 311 . In this case, we hypothesized a relationship between the size of firms and their presence on social media. Our results demonstrate that a relationship can be found between the two variables, as Pearson Chi-Square result in the cross-tabulation analysis is more than the specified $5 \%$ significance level. Based on these, it can be said that the null hypothesis, which does not assume a relationship between the variables, is discarded and the alternative hypothesis is accepted. The symmetric indicators in the table represents the strength of the relationship between the variables.

The results of our second hypothesis are shown in Table 4.

Tab. 4 Analysis of the second hypothesis

\begin{tabular}{|c|c|c|c|}
\hline \multicolumn{4}{|c|}{ Chi-Square Test } \\
\hline Statistics & Value & $\mathrm{df}$ & Asymptotic Significance (2-sided) \\
\hline Pearson Chi-Square & $135,177^{\mathrm{a}}$ & 21 & , 000 \\
\hline Likelihood Ratio & 165,348 & 21 & 000 \\
\hline $\mathrm{N}$ of Valid Cases & 311 & & \\
\hline \multicolumn{4}{|c|}{ Symmetric Measures } \\
\hline & & Value & Approximate Significance \\
\hline \multirow[t]{3}{*}{ Nominal by Nominal } & Phi & 659 & ,000 \\
\hline & Cramer's V & 659 & ,000 \\
\hline & $\begin{array}{l}\text { Contingency } \\
\text { Coefficient }\end{array}$ & ,550 & ,000 \\
\hline $\mathrm{N}$ of Valid Cases & & 311 & \\
\hline
\end{tabular}

Source: own editing based on primary data collection 
In the case of our second hypothesis, we assumed a relationship between the expansion of the future presence in social media and the ways to implement it. In this case, too, the number of valid answers was 311, but based on our results, it can be said that there is no significant relationship between the two variables we examined, because $p<0.05$. Thus, in the case of the second hypothesis, the null hypothesis is accepted.

\section{CONCLUSION}

In the practical part of our study, two research question and two hypotheses were formulated in connection with the topic. In conducting our research, we sought answers to the question of the role of social media in the life of businesses in Nitra district. The first figure shows the distribution of social media presence by company size. Based on the figure, it can be said that the largest number of micro-enterprises are present on social media, followed by small enterprises, and in the third place are medium-sized enterprises. Thus, in the district under study, presence on social media is the most important for micro-enterprises. The result supports the assumption that if a company is small, its presence on social media is more important to it, which is mainly due to the fact that active presence in social media is a suitable solution for branding, communication and also cost effective. Only a small percentage of medium-sized enterprises use social media and the primary reason for which is that in their opinion it is not necessary to expand the number of their target audience, continuous communication is solved in other ways, and they think that the situation is right for them and they do not would like to change. However, the health crisis situation that still exist today is a good example of situations where a business needs to respond extremely quickly to the environmental changes, in which social media can help. It is clear from the figure that most small and medium-sized enterprises are not present on social media, they are not aware of the opportunities provided by social media. For them, we recommend that they should take the opportunity and move into the online space, be the first impression in the hands of the businesses. An online presence makes the organization visible, they can access accurate and up-to-date information about their target audience (which can be a key factor in today's extremely fast-changing world), and they can communicate with consumers. It is important to be aware that the only thing more expensive than advertising is if the business does not advertise. We recommend companies to use platforms where their target audience is present in the largest number. With regard to social media activities, organizations have the opportunity to train their employees as well as employ young, ambitious trainees. It is also important to place a strong emphasis on examining their competitors as they encourage the organization to perform better on a day-to-day basis. In addition, one of the most important factors is the feedback from consumers, which is worth considering and using, as this activity contributes to increasing efficiency and, in the long run, to increasing the existing consumer base. 
Fig. 1 Distribution of social media presence by business size

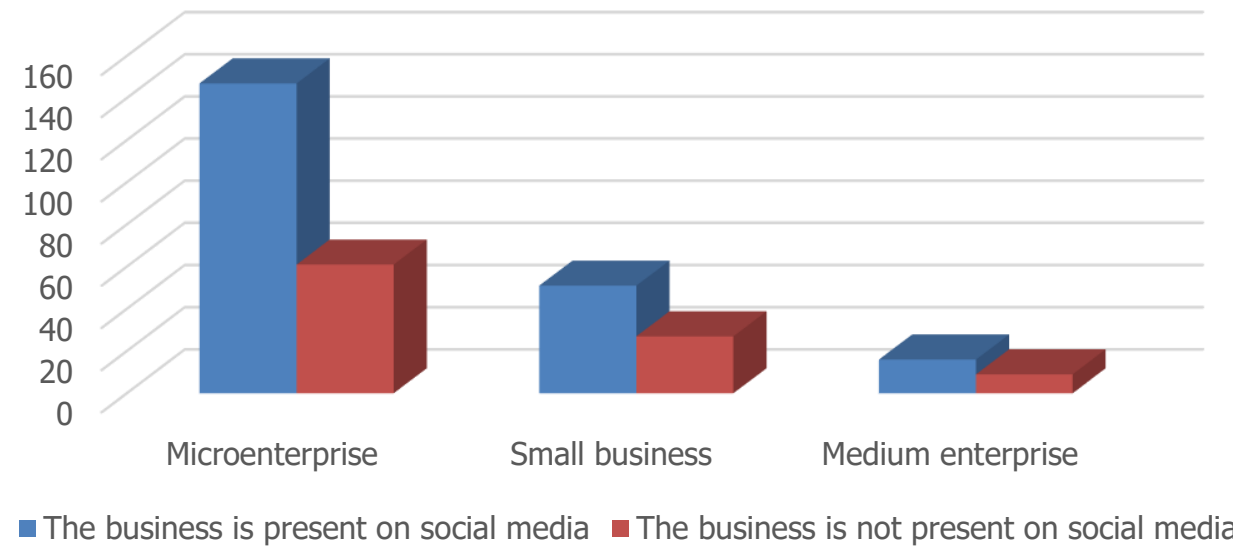

Source: Owned editing based on primary data collection

Our second research question was about what future plans does the research subject have with social media. The results are shown in Figure 2. $43 \%$ of respondents would be willing to expand their presence on social media in the future.

Fig. 2 Distribution of ways to implement future expansion of social media presence

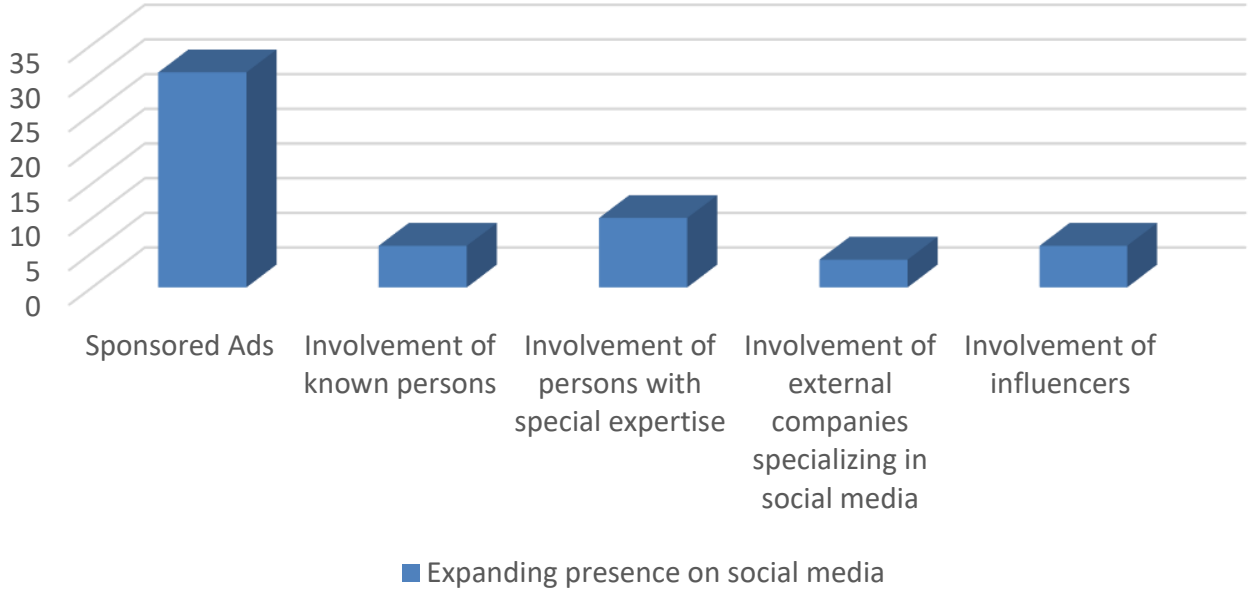

Source: Owned editing based on primary data collection

It is clear that most respondents would implement presence expansion with sponsored ads. This is followed by the involvement of persons with special expertise. We also encourage businesses to appear on other community platforms as well as involve influencers in their related marketing activities. It is important to emphasize that this will only be successful if they include the selected influencer in your current campaign with which the majority of their target audience can identify. In addition, we recommend that they should not afraid to move into the online space, it is never too late to start working in social media. 


\section{REFERENCES}

Aichaner, T. \& Jacob, F. (2015). Measuring the Degree of Corporate Social Media Use. International Journal of Market Research, 57(2), 257-275. https://doi.org/10.2501/IJMR-2015018

Assaad, W. \& Gómez, M. J. (2011). Social Network marketing (Social Media Marketing) Opportunities and Risks. International Journal of Managing Public Sector Information and Communication Technologies. 2(1), 13-22.

Azet.sk. Retrieved 29 January 2021, from https://onas.azet.sk/

Bazalová, L. (2012). Pohlad na sociálne siete a využívanie (Magisterská diplomová práca) Masarykova univerzita - Filozofická fakulta. Ústav české literatury a knihovnictví Kabinet informačních studií a knihovnictví

Csordás, T., Markos, K. É. \& Gáti, M. (2013). A közösségi média, mint stratégiai marketingkommunikációs eszköz. A Magyar Marketing Szövetség Marketing Oktatók Klubja 19. országos konferenciája. (322-334). Budapest.

Georgescu, M. \& Popescul, D. (2015). Social media - The new paradigm of collaboration and communication for business environment. Proccedia Economics and Finance. (20), 277-282. https://doi.org/10.1016/S2212-5671(15)00075-1

História webu. Retrieved 29 January 2021, from https://www.birdz.sk/about/historia/

Murár, P. (2011). Komunálne vol'by 2010 v prostredí sociálnych médií. Výskumné štúdie. Retrieved 29 January 2021, from https://www.communicationtoday.sk/download/1/2011/Murar\%20-\%20CT\%201-2011.pdf

Lide.cz v půlce prosince definitivně končí, seznamka Seznamu si nevydělá na provoz. (2020). Retrieved 29 January 2021, from https://www.lupa.cz/aktuality/lide-cz-v-pulce-prosincedefinitivne-konci-Ska-seznamu-nevydelava/

Risius, M. \& Beck, R. (2015). Effectiveness of corporate social media activities in increasing relational outcomes. Information \& Management, 52(7), 824-839. https://doi.org/10.1016/j.im.2015.06.004

Roblek, V., Bach, P. M., Meško, M. \& Bertoncelj, A. (2013). The impact of social media to value added in knowledge-based industries. Kybernetes, 42(4), 554-568. https://doi.org/10.1108/K-01-2013-0014

Aneta, K. (2018). Služba Spolužáci.cz na konci srpna skončí. Sblog. Retrieved 29 January 2021, from https://blog.seznam.cz/2018/04/sluzba-spoluzaci-cz-na-konci-srpna-skonci/

Spolužáci.cz. Retrieved 29 January 2021, from https://www.ivyhledavace.cz/seznamcz/spoluzaci-cz/

Vzestup a pád Libimseti.cz podle Oldy Neubergera. (2012). Retrieved 29 January 2021, from https://tyinternety.cz/socialni-site/vzestup-a-pad-libimseti-cz-podle-oldy-neubergera/

Zhang, B. \& Vos, M. (2014). Social media monitoring: aims, methods, and challenges for international companies. Corporate Communications: An International Journal, 19(4), 371383. https://doi.org/10.1108/CCIJ-07-2013-0044 